\title{
SLICC 2012: KRITERIA KLASIFIKASI SLE
}

\author{
Prema Hapsari Hidayati* \\ *Bagian Penyakit Dalam Fakultas Kedokteran Universitas Muslim Indonesia Makassar
}

\section{PENDAHULUAN}

Istilah Lupus diambil dari bahasa latin yang berarti serigala dan dipakai pertama kali pada abad pertengahan untuk menggambarkan lesi kulit yang erosive yang mirip dengan gigitan serigala. Pada tahun 1846 seorang ahli dari Vienna bernama Ferdinand von Hebra memperkenalkan istilah "kupu-kupu" untuk menggambarkan rash di daerah malar dan menyebutnya sebagai lupus erythematosus . Ilustrasi ini dipublikasikan pertama kali dalam bukunya berjudul Atlas os Skin Disease pada tahun 1856. Lupus kemudian dibagi menjadi tiga bentuk, yaitu Discoid Lupus Erythematosus,Neonatal Lupus Erythematosus, Drug Induced Lupus dan Systemic Lupus Erythematosus. (Yazdany, 2013)

Systemic Lupus Erythematosus merupakan penyakit autoimun sistemik yang ditandai dengan produksi autoantibodi dengan keterlibatan multiorgan dan manifestasi klinis yang sangat bervariasi.
SLE pertamakali diketahui sebagai penyakit sistemik dengan manifestasi viseral oleh Moriz Kaposi, yang disusul dengan penemuan lesi endocarditis pada pasien SLE oleh Libmann dan Sack di New York pada tahun 1923 . Pada tahun 1935, Baehr juga melaporkan bahwa terjadi perubahan glomerular ginjal yang patologis pada pasien SLE (Maidhof, 2012)

SLE ditemukan hampir di seluruh dunia dengan angka prevalensi dan insiden yang berbeda-beda menurut letak geografisnya. Penelitian menunjukkan bahwa angka kejadian SLE di seluruh dunia sekitar 1-10 per 100.000 orang pertahun dengan angka prevalensi sekitar 20-70 per 100.000 orang pertahun. Di USA angka kejadian SLE untuk semua ras sekitar 5,1 per 100.000 orang pertahun dengan prevalensi diperkirakan 300.000 orang pertahun (Vaillant, 2015)

SLE paling banyak di derita oleh perempuan dengan perbandingan rasio lakilaki $:$ perempuan $=1: 12$ pada usia subur. Selain itu penyakit ini juga bisa didapatkan 
pada anak-anak dan lansia. SLE lebih banyak didapatkan pada ras non Caucasian seperti African American, Hispanic, dan asia. Pada ras-ras tersebut, SLE cenderung lebih aktif, lebih berat, resiko relaps dan terjadinya kerusakan organ lebih tinggi. (Vaillant, 2015)

Walaupun beberapa tahun terakhir banyak didapatkan kemajuan dalam hal diagnosis dan terapi, namun resiko kematian pada pasien SLE masih lebih tinggi dibandingkan populasi umum. Pada pasien yang baru di diagnosis SLE, angka harapan hidup 5 tahun kedepan lebih dari 90\%, sedangkan angka harapan hidup 15-20 tahun kedepan $80 \%$. Prognosis yang buruk dan peningkatan resiko kematian berhubungan etnisitas dan social ekonomi (Maidhoff, 2012)

Di Indonesia, tren penyakit SLE pada pasien rawat inap rumah sakit terdapat peningkatan sejak tahun 2014 -2016. Jumlah penderita Lupus pada tahun 2016 dilaporkan ada sekitar 2.166 kasus. Jumlah ini meningkat hampir dua kali lipat dibanding tahun 2014, yaitu sebanyak 1.169 kasus. Jumlah kematian pasien Lupus pada tahun 2016 juga mengalami peningkatan, yaitu sebanyak 550 kematian. Ada beberapa faktor yang berpengaruh terhadap tingginya angka kematian pada pasien lupus di Indonesia antara lain kurangnya pemahaman dokter layanan primer mengenai kriteria diagnostik
SLE, sehingga terjadi keterlambatan diagnosis dan terapi (Pusdatin 2017)

Oleh karena itu pada artikel ini dibahas bagaimana mengenali penyakit SLE menurut kriteria klasifikasi ACR dan SLICC serta efektivitas keduanya dalam menegakkan diagnosis SLE.

\section{KRITERIA KLASIFIKASI SLE}

Manifestasi klinik penderita SLE bisa sangat bervariasi mulai dari nyeri sendi atau kelainan kulit yang ringan sampai kelainan organ internal yang berat dan mengancam nyawa. Sampai saat ini belum ada pemeriksaan gold standart untuk mendiagnosis SLE. Diagnosis SLE biasanya ditegakkan berdasarkan penilaian dari ahli yang berpengalaman yang dapat mengidentifikasi kerakteristik, gejala dan hasil laboratorium yang sesuai dengan SLE sambil menyingkirkan semua diagnosis banding. Diagnosis menjadi sulit apabila gejala yang muncul tidak khas atau tidak muncul secara bersamaan (Aringer, 2016)

Sampai saat ini belum ada kriteria diagnosis yang disepakati untuk mendiagnosis SLE, yang sudah ada adalah kriteria klasifikasi yang digunakan dalam penelitian SLE. Pada tahun 1971 Cohen dkk menerbitkan kriteria klasifikasi pertama untuk SLE yang terdiri dari 14 kriteria 
klasifikasi SLE. Kemudian pada tahun 1982, Tan dkk merevisi kriteria tersebut seiring dengan kemajuan ilmu kedokteran mengenai tes serologi, yaitu antibodi antinuklear (ANA) dan anti-dsDNA. Kemudian pada tahun 1997 dilakukan revisi lagi yang dikenal dengan kriteria American Rheumatism Association (ARA/ACR). Namun sayangnya kriteria ini tidak pernah divalidasi (Tan, 1982; Hochberg, 1997)

Kriteria ARA pada awalnya dimaksudkan untuk menjadi kriteria pada penelitian bukan sebagai kriteria diagnosis yang bersifat eksklusif dan membatasi. Kriteria diagnostik harus dapat diterapkan pada subjek manapun di dunia, dan harus mencakup variabel imunologi yang divalidasi pada populasi yang berbeda, yang masih sulit terpenuhi.Namun, kenyataan yang berkembang kemudian tidak demikian, kriteria ini malah digunakan secara luas oleh klinisi untuk diagnosis SLE. Akibatnya dapat sering menimbulkan "misdiagnosis" (Aringer, 2016)

Selain itu bisa terjadi keterlambatan diagnosis SLE karena pada saat terpenuhi empat poin sesuai syarat kriteria ARA 1997, pasien mungkin telah lama menderita SLE, dan telah terjadi kerusakan organ yang cukup berat. Sebenarnya Tan dkk sudah mengingatkan agar berhati-hati, karena kriteria tersebut dan agar tidak digunakan sebagai kriteria diagnostik yang benar sampai tes yang lebih luas terhadap berbagai jenis penyakit telah dilakukan. Kriteria tersebut sengaja dibuat sederhana agar memudahkan pengajaran dan aplikasi praktis untuk kepentingan penelitian (Aringer, 2016)

SLICC (Systemic Lupus International Collaborating Clinics) adalah suatu kelompok penelitian mengenai SLE yang sudah berdirir sejak 30 tahun yang lalu, yang juga berperan dalam pengembangan indeks ACR/SLICC Damage. SLICC mencatat beberapa kekurangan kriteria ACR yaitu antara lain : banyak pasien yang diklasifikasikan sebagai SLE tapi tanpa didapatkan kriteria imunologi satupun, terlalu fokus terhadap manifestasi kulit yang khas dan kurang memperhatikan menifestasi kulit lupus bentuk lain, banyak manifestasi neurologi yang spesifik SLE tidak diperhitungkan, kuantifikasi protein urin harus di modifikasi menggunakan standar baru , tidak dimasukkannya kadar komplemen serum yang rendah dan antibodi anti fosfolipid pada kriteria imunologi, pasien nefritis dengan biopsi ginjal sesuai lupus nefritis mungkin tidak diklasifikasikan SLE, dan belum adanya validasi kriteria ACR 1997(Petri, 2012) 
Dengan maksud untuk meningkatkan relevansi klinis dari kriteria ACR, maka SLICC memasukkan penemuan terbaru dalam imunologi SLE, menambah hal - hal yang kurang dari kriteria ACR 1997 dan melakukan validasi. Hasilnya kemudian di publikasikan pada tahun 2012 dan di sebut kriteria SLICC (Petri,2012).

Tabel 1. Kriteria Klasifikasi SLICC untuk SLE (Petri, 2012)

\begin{tabular}{|c|c|}
\hline \multicolumn{2}{|l|}{ KRITERIA KLINIS } \\
\hline 1. Lupus kutaneus akut & $\begin{array}{l}\text { Meliputi ruam malar lupus (jangan dimasukkan bila diskoid } \\
\text { malar);lupus bula; varian nekrolisis epidermal toksik dari } \\
\text { SLE; ruam lupus makulopapular; ruam lupus fotosensitif } \\
\text { tanpa deramtomiositis; atau lupus kutan subakut } \\
\text { (nonindurated psoriaform dan/atau lesi polisklik anular yang } \\
\text { sembuh tanpa jaringan parut, walaupun kadang-kadang } \\
\text { disertai depigmentasi atau telengiektasis postinflamasi) }\end{array}$ \\
\hline 2. Lupus kutaneus kronik & $\begin{array}{l}\text { Meliputi ruam diskoid klasik; terlokalisir (di atas leher); } \\
\text { generalisata (di atas dan di bawah leher); lupus hipertrofik } \\
\text { (verukous); lupus panniculitis (profundus); lupus mukosa; } \\
\text { lupus eritematous tumidus; lupus chilblains; lupus } \\
\text { discoid/overlap dari liken planus }\end{array}$ \\
\hline 3. Ulkus Oral dan nasofaringeal & $\begin{array}{l}\text { Ulkus di palatum, buccal, lidah, atau nasal disingkirkan } \\
\text { penyebab lain seperti vaskulitis, behcet, herpes, IBD, } \\
\text { reaktif artritis, makanan asam }\end{array}$ \\
\hline 4. Alopesia non scarring & $\begin{array}{l}\text { Penipisan difus rambut, rambut gampang patah } \\
\text { disingkirkan dulu alopesia areata, obat-obatan, defisiensi } \\
\text { besi, alopesia androgenik. }\end{array}$ \\
\hline 5. Sinovitis $>2$ sendi & $\begin{array}{l}\text { Nyeri } 2 \text { sendi atau lebih disertai dengan edema atau efusi } \\
\text { disertai dengan kekakuan sendi pagi hari. }\end{array}$ \\
\hline 6. Serositis & $\begin{array}{l}\text { Pleuritis tipikal selama lebih dari } 1 \text { hari atau efusi pleura } \\
\text { atau pleural rub; nyeri perikardial tipikal (nyeri yang } \\
\text { diperberat dengan duduk membungkuk) selama lebih dari } 1\end{array}$ \\
\hline
\end{tabular}




\begin{tabular}{|c|c|}
\hline & $\begin{array}{l}\text { hari atau efusi perikard atau pericardial rub atau perikarditis } \\
\text { oleh gambaran elektrokardiografi tanpa penyebab lain } \\
\text { seperti infeksi, uremia dan perikarditis Dressler }\end{array}$ \\
\hline 7. Manifestasi ginjal & $\begin{array}{l}\text { Protein urin/ kreatinin atau protein urin } 24 \text { jam (500 mg } \\
\text { atau lebih) atau ada cast eritrosit }\end{array}$ \\
\hline 8. Manifestasi neurologi & $\begin{array}{l}\text { Kejang, psikosis, mononeuritis multiplex ( singkirkan } \\
\text { penyebab vaskulitis primer) myelitis, neuropati perifer } \\
\text { (disingkirkan penyebab lain seperti vaskulitis primer, } \\
\text { infeksi, diabetes mellitus), acute confusional state (tanpa } \\
\text { penyebab lain : metabolik, uremia, obat) }\end{array}$ \\
\hline 9. Anemia Hemolitik & \\
\hline 10. Leukopenia / limfopenia & $\begin{array}{l}\text { Leukopenia <4000mm3 (disingkirkan penyebab lain } \\
\text { seperti : obat-obatan, dan hipertensi portal) Limfopenia } \\
<1000 \mathrm{~mm} 3 \text { dengan disingkirkan penyebab lain : terapi } \\
\text { steroid, infeksi }\end{array}$ \\
\hline 11. Trombositopenia & $\begin{array}{l}<100,000 \mathrm{~mm} 3 \text { (sudah disingkirkan penyebab lain : obat2an, } \\
\text { hipertensi portal dan TTP) }\end{array}$ \\
\hline \multicolumn{2}{|l|}{ KRITERIA IMUNOLOGI } \\
\hline 12. ANA & Diatas nilai normal \\
\hline 13. Anti DS DNA & $\begin{array}{l}\text { Diatas nilai normal kecuali ELISA: duakali diatas nilai } \\
\text { normal }\end{array}$ \\
\hline \multicolumn{2}{|l|}{ 14. Anti Sm } \\
\hline 15. Antibodi anti fosfolipid & $\begin{array}{l}\text { Anti koagulan lupus anticoagulant, RPR false positif, titer } \\
\text { anticardiolipin ( } \operatorname{IgA}, \operatorname{IgG} \text { or } \operatorname{IgM}) \text { medium atau tinggi dan } \\
\text { beta 2-glycoprotein } \mathrm{I}(\operatorname{Ig} \mathrm{A}, \operatorname{IgG} \text { or } \operatorname{IgM})\end{array}$ \\
\hline 16. Kadar komplemen rendah & Kadar C3, C4 or CH50 rendah \\
\hline 17. Direct Coomb tes yang positif & Tanpa adanya gambaran anemia hemolitik \\
\hline
\end{tabular}

Pada kriteria SLICC terdiri dari 11 kriteria klinis dan 6 kriteria imunologi. Seseorang diklasifikasikan telah menderita
SLE apabila memenuhi 4 kriteria yang harus meliputi 1 kriteria klinis dan 1 kriteria imunologi. Atau apabila hasil biopsi ginjal 
pasien sesuai dengan gambaran lupus nefritis disertai ANA dan anti DSDNA yang positif. Kriteria-kriteria ini tidak harus didapatkan bersamaan. Sedangkan pada kriteria ACR 1997 terdiri dari 11 kriteria, dan pasien di klasifikasikan sebagai SLE bila memenuhi 4 dari 11 kriteria tersebut (Petri,2012).

Tabel 2. Perbandingan Kriteria Klasifikasi ACR 1997 dan SLICC (Petri, 2012; Tan, 1997)

\begin{tabular}{|c|c|}
\hline SLICC & ACR 1997 \\
\hline \multicolumn{2}{|l|}{ KRITERIA KLINIS } \\
\hline 1. Lupus kutaneus akut & 1. Ruam Malar \\
\hline 2. Lupus kutaneus kronik & 2. Ruam Diskoid \\
\hline 3. Ulkus oral dan nasofaringeal & 3. Fotosensitivitas \\
\hline 4. Alopesia non Scarring & 4. Ulkus oral/ nasal \\
\hline 5. Sinovitis $>2$ sendi & $\begin{array}{l}\text { 5. Artritis non erosif mengenai } 2 \text { sendi atau } \\
\text { lebih }\end{array}$ \\
\hline 5. Serositis & 6. Pleuritis or pericarditis \\
\hline 7. Manifestasi ginjal & 7. Kelainan ginjal : proteinuria persisten \\
\hline 8. Manifestasi Neurologi & 8. Kelainan neurologi : kejang atau psikosis \\
\hline 9. Anemia Hemolitik & $\begin{array}{l}\text { 9. Kelainan hematologi : anemia hemolytic, } \\
\text { leukopenia, limfopenia, trombositopenia }\end{array}$ \\
\hline 10. Leukopenia / limfopenia & 10. ANA tes positif \\
\hline 11. Trombositopenia & $\begin{array}{l}\text { 11. Kelainan imunologi } \\
\text { - Anti-DS DNA } \\
\text { - Anti-Sm } \\
\text { - Antibodi anti fosfolipid } \\
\text { a) IgG atau IgM anticardiolipin } \\
\text { b) Lupus antikoagulan (LA) atau } \\
\text { c) tes sifilis yang false positive }\end{array}$ \\
\hline \multicolumn{2}{|l|}{ KRITERIA IMUNOLOGI } \\
\hline 12. ANA & \\
\hline 13. Anti DS DNA & \\
\hline
\end{tabular}




\begin{tabular}{|l|}
\hline 14. Anti Sm \\
\cline { 1 - 1 } 15. Antibodi Anti Phospholipid \\
\cline { 1 - 1 } 16. Kadar komplemen yang rendah \\
\cline { 1 - 1 } 17. Direct Coomb tes yang positif \\
\hline
\end{tabular}


Selain mengajukan kriteria baru, SLICC juga melakukan validasi terhadap kriteria tersebut dan membandingkannya dengan kriteria ACR 1997. Hasilnya dapat dilihat pada tabel 3. Walaupun didapatkan nilai spesifisitas yang lebih rendah, namun jumlah pasien yang misklasifikasi dengan menggunakan kriteria SLICC lebih sedikit dibandingkan apabila menggunakan kriteria ACR 1997. Pada sampel penelitian validasi, kriteria SLICC salah mengklasifikasikan lebih sedikit kasus dan memiliki sensitivitas yang lebih tinggi namun memiliki nilai spesifisitas lebih rendah. Namun perbedaan atara kedua kriteria tidak signifikan secara statistik (Petri, 2012)

Tabel 3. Perbandingan kriteria SLICC dengan Kriteria ACR 1997 (Petri,2012)

\begin{tabular}{|c|c|c|c|}
\hline & $\begin{array}{c}\text { Sensitivita } \\
\text { s }\end{array}$ & $\begin{array}{c}\text { Spesifisit } \\
\text { as }\end{array}$ & $\begin{array}{c}\text { Misklasifik } \\
\text { asi }\end{array}$ \\
\hline $\begin{array}{c}\text { Kriteri } \\
\text { a ACR } \\
1997\end{array}$ & $\begin{array}{c}290 / 349 \\
(83 \%)\end{array}$ & $\begin{array}{c}340 / 349 \\
(97 \%)\end{array}$ & 74 \\
\hline Kriteri & $326 / 341(9$ & $288 / 341$ & \\
a & $6 \%)$ & $(84 \%)$ & 62 \\
SLICC & & & \\
\hline
\end{tabular}

Publikasi kriteria klasifikasi SLE yang baru ini kemudian disusul oleh beberapa penelitian yang menilai efektivitasnya dan membandingkan dengan kriteria ACR, dan didapatkan hasil yang bervariasi. Pada penelitian yang dilakukan di swedia SLICC menunjukkan sensitivitas $94 \%$ dibandingkan kriteria ACR 1997 yang hanya $90 \%$, sedangkan kriteria kriteria ACR 1982 gagal mengidentifikasi 5 kasus SLE. Walapun begitu spesifisitas kriteria SLICC hanya 74\% (Ighe, 2015). Sedangkan pada penelitian yang dilakukan oleh Amezcua-guerra tahun 2015 mendapatkan hasil bahwa sensitivitas dan spesifitas kriteria SLICC 2012 adalah 92\% dan 99\%, sedangkan sensitivitas dan spesifisitas kriteria ACR 1997 adalah 97\% dan 99\%.(Amezcuaguerra,2015)

Dengan menggunakan
kriteria SLICC pasien yang
menderita SLE dapat lebih cepat
terdiagnosis, hal ini dikonfirmasi
oleh pada penelitian yang dilakukan
Ines dkk pada tahun 2015 dengan
sampel berjumlah 2055 pasien yang
terdiagnosis secara klinis,


mendapatkan hasil bahwa kriteria SLICC 2012 lebih sensitive dibandingkan kriteria ACR dan dengan menggunakan kriteria SLICC memungkinkan deteksi SLE pada stadium awal (Ines, 2015). Begitu juga penelitian yang dilakukan Aberle dkk pada tahun 2016 pada rekam medik dari 3575 pasien yang terdiagnosis SLE didapatkan hasil kriteria SLICC dapat mengklasifikasikan kasus lebih banyak dibandingkan kriteria ACR. Individu yang terklasifikasi sebagai SLE oleh kriteria SLICC memiliki manifestasi yang heterogen termasuk adanya potensi keterlibatan organ mayor. Penelitian ini memberikan data yang mendukung bahwa kriteria SLICC lebih inklusif pada individu dengan SLE pada penelitian klinis (Aberle, 2016)

Selain itu, SLICC juga berhubungan dengan aktvitas penyakit SLE, hal ini tampak pada penelitin cross sectional pada 110 pasien SLE di Kroasia, dengan hasil didapatkan korelasi yang cukup kuat antara kriteria klasifikasi SLICC dan indeks aktivitas SLE (SLEDAI). Tapi tidak didapatkan hubungan antara kriteria klasifikasi ACR dengan SLEDAI. Kriteria SLICC berhubungan dengan aktivitas penyakit karena memasukkan lebih banyak gejala klinis dan laboratoris yang juga ada pada indeks SLEDAI. Ada lebih banyak pasien yang memenuhi kriteria neurologi dan hematologi dari kriteria SLICC daripada kriteria ACR (Anic, 2014)

Di Indonesia, pada penelitian yang dilakukan oleh Karuniawaty di RSUP Dr Sardjito pada pasien anak yang didiagnosis SLE, mendapatkan dari 64 pasien yang di diagnosis SLE, yang memenuhi keriteria ACR sekitar 71,9\% sedangkan yang memenuhi kriteria SLICC 60,9\%. Sehingga agreement diantara kedua penelitian cukup baik (Karuniawaty, 2016)

Walaupun telah banyak penelitian yang mendukung penerapan kriteria SLICC untuk mengklasifikasikan SLE, namun beberapa peneliti lain mendapatkan spesifisitas kriteria SLICC yang masih rendah dibandingkan kriteria ACR. Sehingga kedua kriteria ini tetap bisa digunakan untuk saling melengkapi . Namun baik kriteria ACR maupun SLICC masih tetap belum bisa dijadikan sebagai kriteria 
diagnosis SLE. Oleh karena itu, saat ini para ahli rematologi dunia masih terus berusaha merumuskan kriteria yang tepat untuk mendiagnosis SLE, yang diperkirakan akan dipublikasikan pada akhir 2017 atau awal 2018 ini (Aringer, 2016).

\section{KESIMPULAN}

Sampai saat ini,etiologi pasti SLE masih belum diketahui dan untuk menegakkan diagnosis SLE masih merupakan tantangan bagi para klinisi karena manifestasi penyakit yang sangat luas dan bervariasi. Belum ada kriteria diagnosis yang tepat untuk dijadikan dasar mendiagnosis SLE, yang ada adalah kriteria klasifikasi yang digunakan dalam penelitian. Saat ini telah ada beberapa kriteria klasifikasi SLE yaitu kriteria ACR 1971, 1982, 1997 dan yang terakhir adalah kriteria SLICC tahun 2012. Kriteria SLICC memiliki sensitivitas untuk mendiagnosis SLE lebih baik daripada riteria ACR 1997, tapi tidak spesifisitas. Kriteria SLICC lebih relevan secara klinis sehingga memungkinkan memasukkan lebih banyak pasien yg secara klinis diduga SLE . SLICC merupakan kriteria yang sederhana tapi meliputi gejala-gejala klinis penting dan menifestasi imunologi yang membuat kriteria ini mempunyai nilai lebih dan dapat digunakan sebagai alat bantu untuk menegakkan diagnosis SLE

\section{DAFTAR PUSTAKA}

1. Yazdany J, Dall'Era M. Definition and Classification lupus and Lupus related disorder. Duboi's Lupus Erythematosus and Related Syndromes. 2013. $8^{\text {th }}$ edition. pp1-7

2. Maidhof W, Hilas O. Lupus: An Overview of the DiseaseAnd Management Options. P\&T• April 2012 • Vol. 37 No. 4

3. Valliant AJ, Akpaka PE, Poonking P. Systemic Lupus Erythematosus : some Epidemiology aspects. American Journal of Public Health Research, 2015, Vol. 3, No. 2, 46-50

4. Pusat Data dan Informasi (Pusdatin) Kementrian Kesehatan RI, Pedoman Pengendalian Penyakit Lupus Eritematosus Sistemik (LES).2017 
5. Aringer M, Dorner T, Leuchten N, Johson SR. Toward New Criteria for Systemic Lupus Erythematosus a Standpoint. Lupus 2016;25:805-811

6. Tan EM, Cohen AS, Fries JF, et al. The 1982 revised criteria for the classification of systemic lupus erythematosus. Arthritis Rheum 1982; 25: 1271-1277.

7. Petri M, Orbai AM, Alarcon GS, et al. Derivation and validation of Systemic Lupus International Collaborating Clinics classification criteria for systemic lupus erythematosus. Arthritis Rheum 2012; 64: 2677-2686

8. Hochberg MC. Updating the American College of Rheumatology revised criteria for the classification of systemic lupus erythematosus. Arthritis Rheum 1997; 40: 1725

9. Ines L, Silva C, Galindo M, Lopez-longo FJ, Terroso G, Romao VC et al. Classification of Systemic Lupus Erythematosus : Systemic Lupus International Collaborating Clinics Versus American College of Rheumatology Criteria. A Comparative Study of 2,055
Patients from Real-Life, International Systemic Lupus Erythematosus Cohort. Arthritis Care \& Research 2015;67: 11801185

10. Aberle T, Bourn RL, Chen H, Roberts VC, Guthridge JM, Bean $\mathrm{K}$ et al. Use of SLICC criteria in a Large, diverse Lupus Registry enables SLE classification ofa subset of ACR-designated subjects with incomplete lupus. Lupus Science \& Medicine 2017; 4:e000176. Doi:10.1136/lupus2016-000176.

11. Ighe A, Dahlstrom O, Skogh T, Sjowall C. Application of the 2012 Systemic Lupus International Collaborating Clinics classification criteria to patients in regional Swedish systemic lupus erythematosus register. Arthritis Research \& Therapy 2015; 17:3 DOI 10.1186/s13075-015-0521-9

12. Anic F, Zuvic-Buorac M, Stimac D, Novak S. New Classification criteria for systemic lupus erythematosus correlate with disease activity. Croat Med J 2014;55:514-9 
13. Karuniawaty TP, Sumadiono, Satria CD. Perbandingan Diagnosis Systemic Lupus Erythematosus Menggunakan Kriteria American College oh Rheumatology dan Systemic Lupus International Collaborating Clinics. Sari Pediatri 2016;18(4): 299-303

14. Hochberg M C et al. Updating the American College of Rheumatology revised criteria for the classification of systemic lupus erythematosus. Arthritis Rheum 1997 Sep;40 (9):1725.
15. Amezcua-Guerra LM, HigueraOrtiz V, Arteaga-Garcia U, Gallegos-Nava S, Hubbe-Tena C. Performance of the 2012 Systemic Lupus International Collaborating Clinics and the 1997 American College of Rheumatology Classification Criteria for Systemic Lupus Erythematosus in Real- life Scenario. Arthritis care \& research 2015;67(3):473-441 